\title{
The Nature of the Exile:
}

\section{Discourse and Power in The Thief of Bagdad (1940)}

\section{Gábor Gergely}

\section{Contextualising the Subject}

The Thief of Bagdad was a spectacular Technicolor production by Alexander Korda's London Films studio. It was one of Korda's biggest successes, matching the very profitable The Private Life of Henry VIII (1933), which made $£ 500,000$ in its first world-wide release (Christie 1985: 44), and 'was UA's top-grossing film out of twenty released in 1940, earning just over a million dollars in domestic rentals' (Street 2002: 58). The film tells the story of Ahmad (John Justin), the King of Bagdad, whose throne is usurped by his Grand Vizier, Jaffar (Conrad Veidt). Jaffar hopes to marry the daughter of the Sultan of Basra, the most beautiful woman in the world. The dispossessed Ahmad is joined by the lowly thief Abu (Sabu), who helps him in his quest to recover his throne and his love, the Princess of Basra (June Duprez). After a series of fantastic adventures, Abu and Ahmad succeed in finding their way back to Bagdad and rescue the Princess. Ahmad then confronts Jaffar, who escapes on the back of a flying horse. Abu shoots him in the head with an arrow-gun and Ahmad, reunited with his love, takes his rightful place on the throne of Bagdad.

What is interesting in relation to critical readings of The Thief of Bagdad is that they tend to favour an exploration of representations of the East in Western culture over any other approach. Nadel considers the film briefly in Bernstein and Studlar's Visions of the East (1997: 184-203); Eisele (2002), writing about the genre 
conventions of the 'eastern', pauses to discuss the film cursorily and chiefly in relation to the original 1924 film by Raoul Walsh (74; 79); while Jaikumar (2006) in his sensitive and insightful readings of the films and roles of Sabu, affords The Thief of Bagdad, with its Arabian, rather than Indian setting, fewer mentions than, for instance, The Drum (Zoltán Korda, 1938), which is set in the Raj. What these pieces have in common is that they examine cinema in terms of the representation of 'the other'. But, as I would like to argue, productions such as The Thief of Bagdad are also often representations of the nation where they were made. Indeed, Korda's film went into pre-production as war loomed on the Continent and premiered in London in the midst of Nazi bomb raids. Moreover, its story of a benign kingdom usurped by a foreign parvenu, corrupted, compromised, transformed into an empire of terror, not only echoed the rise to power of Hitler in Germany and the birth of the Third Reich, but also invoked deep concerns in Britain about the possibility of sustaining a democratic system in the face of Fascism and Nazism running rampage throughout Europe. Thus, it would be limiting to read this film as one reflecting solely on the Middle East and its peoples. It is equally productive to consider The Thief of Bagdad as a filmic response to a particularly tense international situation and, crucially, one that explores threats to the nation transposed to an exotic setting.

Although made primarily in England, the production of The Thief of Bagdad was completed in America and as such has much in common with Hollywood cinema. As Street points out (2002: 58), it was one of the top-grossing films of 1940 in the US market, and with the eminently recognisable backdrop of the Grand Canyon where some of the exteriors were shot it is easy to mistake it for an American film. This was by no means accidental: Alexander Korda's commercial ambitions meant that his placed an emphasis on the spectacular in an effort to improve their chances at the 
American box office. Moreover, The Thief of Bagdad is a loose remake of Raoul Walsh's 1924 silent spectacular starring Douglas Fairbanks. While the use of Technicolor dictated a reliance on the technology, expertise and creative talent of Hollywood; associate producer William Cameron Menzies ${ }^{1}$, for instance, is to be credited with the look of the film as much as the uncredited set designer, the youngest Korda brother, Vincent.

The film's Hollywood flavour is reaffirmed by the near-universal silence surrounding it in British film historiography. It is totally absent in key works on British cinema by Ashby and Higson (2000), Sargeant (2005), Barr (1986) and Drazin (1998); while those by Aldgate and Richards (1999), Murphy (2001), Armes (1978) and Low (1979) afford it only the most fleeting mention. In a recent article Drazin gives an overview of Korda's Technicolor films in which The Thief of Bagdad appears, almost as an afterthought (2010: 18). And even Glancy's (1999) book, When Hollywood Loved Britain: the 'Hollywood' British Film 1939-1945, omits any mention of the film. Indeed, the most 'exhaustive' analysis of The Thief of Bagdad in overviews of British cinema is a paragraph devoted to it by Landy (1991: 110), who remarks on the film's focus on the spectacular and the problematic representation of foreigners and women (Sabu and Duprez), but, puzzlingly, has nothing to say about Veidt. $^{2}$

It is this critical silence around the film, and more generally around the star body of Conrad Veidt, that I seek to redress here. While it may be a stretch to argue that Jaffar is the hero of the piece, I will consider his character as victim, as the rejected, denied and excluded 'other'. I read Veidt's star body as an exilic body, and analyse Jaffar, his actions, motivations and representation, through a cultural studies approach concerned above all with the issue of exile. This essay offers, then, a 
detailed textual analysis of a key performance by a significant exilic actor in the starring role of a Technicolor super-production in order to show that there is more to cinema and exile than the tragic irony of exilic actors playing their own persecutors (Garncarz 2006: 103-114), or the counter-hegemonic inflection of the film style of 'accented' filmmakers (Naficy 2001: 4). The Thief of Bagdad (re)presents the exilic body in hitherto unconsidered ways, contributing to a normative discourse constructing the nation within a binary system best described as 'us versus them'. Consequently, it is the role played by exilic bodies (irrespective of their individual histories of persecution and refuge) within this binary that this essay is most concerned with.

While continuing research into the films of exilic directors is vitally important to further debates surrounding exile, it is just as important to trace representations of exile in Hollywood and 'Hollywood British' cinema. Analyses of the works of exilic directors, as in Naficy's approach, can shed light on their personal experiences of exile, but an investigation of representations of exile within the heavily regulated studio system of Hollywood can help us understand general and prevailing attitudes to exiles and immigrants. While a number of Jewish actors played Nazis in Hollywood films, they were, by and large, less well-known character actors in minor roles (Garncarz 2006: 103) and the more prominent Nazis were usually portrayed by British actors like Cedric Hardwicke, Claude Rains and Basil Rathbone rather than émigrés or refugees from Continental Europe. There were, however, a number of major European stars, including Charles Boyer, Paul Henreid, Paul Lukas, Béla Lugosi, Conrad Veidt, Peter Lorre, who continued to enjoy star status and billing in Hollywood and who played a wide variety of characters not restricted to villainous 
Nazis. ${ }^{3}$ A closer analysis of these figures offers a rich field of enquiry that can inaugurate productive new debates in the area of exile and cinema.

In order to clarify and render distinct the analytical approach I am adopting, it is helpful to briefly consider the major critical trends in writings on exile and cinema. One approach takes as its focus the films of exilic directors. This is a fundamentally auteurist approach, perhaps best represented by Hamid Naficy (2001), where the personal experiences of the director are related by the scholar to particular stylistic and narrative traits of the director's films. Thus, fragmented narratives and alienating stylistic features are understood to relate to the rupture and displacement of exile and representation is analysed from the point of view of the director in control of the process of representation.

Another major trend in scholarship focuses on the destiny of exiles within the 'host' system (generally Hollywood), thus comprising a fundamentally empirical approach where archival research provides a basis for understanding the repercussions of exile. Films are held up as examples of how the creative intent of the exilic artist has been variously thwarted or asserted by the functioning of the Hollywood studio system. This approach allows a consideration of the artistic and financial limitations imposed upon exilic artists in the system within which they operate after displacement. Such an approach is predominantly suited for a compare-and-contrast (or binary) analysis of the exilic artist's work before and after displacement; shedding light on generally prevailing attitudes to exile within the system of cinema, but not necessarily on those within the system of 'nation'. The prime exponents of this approach include Bergfelder (2008), Elsaesser (2000 and 2005), Sreet (2002), Vincendeau and Phillips (2006). 
The third trend, which as yet has fewer exponents than the previous two, approaches the issue from the angle of the performance of exilic actors. It focuses on the representation of exile and exilic bodies, analysing meanings inscribed into the exilic body. But here films are not cited as sites of struggle over creative control, rather they are articulations of exile by the exilic performers. An exponent of this approach is Gert Gemünden, who analyses the films of Conrad Veidt in Bergfelder's Destination London (2008), and those of Peter Lorre in McCarthy's Light Motives (2003). A problem with this approach however is its underlying assumption that the output of exilic actors can be read as works of art in which an authorial voice can be attributed to the exilic actors. Yet there are various difficulties that follow from this basic assumption. First, as the case of Béla Lugosi or Peter Lorre illustrates, actors were very rarely in a position to pick and choose between parts. In Hollywood they had even less influence on script: any tendency to ad-lib or suggest changes would have been seen as a sign of an actor being 'difficult' to work with, a practical deathsentence in the studio system. Consequently, it is only be safe to read exilic actors' performances as individual reflections on individual experiences; but this inevitably locates such performances in a hermetically sealed cell, preventing us from drawing any general conclusions on the basis of our case studies.

Whilst this essay will shift and adjust the focus of all three approaches to some degree, it will concentrate primarily on the text, and in particular on the role and performance of the exilic star, and the representation of the exilic body within a specific Hollywood-British-hybrid text.

Before first of all, I will give a brief account of Conrad Veidt's career prior to exile and after his emigration from Germany in the winter of 1932 . The son of a petitbourgeois family in Berlin (Allen 1987: 4), Veidt came to acting early and by 1918, at 
the age of 25 , he was a veteran of the stage and a regular on the rapidly developing German film scene. Over the next two decades he built an impressive body of work, appearing in various milestones of German cinema from the seminal Expressionist work Das Cabinett des Dr Caligari (Robert Wiene, 1919) through Der Student von Prag (Henrik Galeen, 1926) to the Europe-wide hit Der Kongress tanzt (Eric Charell, 1931). The English-language version of the latter, The Congress Dances (Eric Charell, 1931), in which Veidt reprised his role of Prince Metternich, cemented his stardom in the UK and laid the foundations for his subsequent career there, initially with Gaumont British and later at London Films. Veidt maintained his high profile after emigrating and in 1934 he was named Best British Actor by Picturegoer Magazine (Ibid.: 224).

In the German phase of his career, Veidt alternated between roles of monsters or monstrous villains and romantic leads. But in England, where he settled in late 1932 before Hitler's rise to power, his profile changed subtly. Fewer romantic leads came his way, but also, interestingly, he played fewer monsters. Instead, from Jew Suss (Lothar Mendes, 1934) through the Jerome K Jerome-scripted The Passing of the Third Floor Back (Berthold Viertel, 1935) to The Spy in Black (Michael Powell, 1939) and Contraband (also Powell, 1940) he tended to portray mysterious strangers who, whether friend or foe, were always the very embodiment of Continental courtesy and an unbending decency. But in The Thief of Bagdad his character was strikingly different to those he had grown used to playing during his years in England. Instead of a fundamentally decent, honest and principled man, here he plays a vicious but sly foreigner. His character, Jaffar, is represented as a cowardly schemer who is the architect of a coup d'état and, in this, is far closer to the villains he subsequently portrayed in Hollywood, most notably in Casablanca (Michael Curtiz, 1942). 
White Lies - the 'Other' as Represented in Normative Discourse

The Thief of Bagdad begins with the return of Jaffar from a voyage. The crimson sails of his galleon billow in the wind as the ship glides into Basra harbour; Jaffar, in a red turban, his face covered by a red scarf, looks out across the colourful city with hungry eyes. He gives the impression of a man who wants to have it all: the city, its riches, its people. On his way back to the palace, Jaffar overhears the plaintive calls of a blind beggar for 'alms in the name of Allah' and orders his guards to escort the beggar to the palace. There, the beggar begins his sad tale about a kingdom lost, a love lost and eyesight lost, all to the evil Vizier, Jaffar. We then witness the story unfold: as recounted by its putative protagonist, the cheated, dispossessed Ahmad. He begins by describing himself: 'There was once a king: son of a king and of a hundred kings; his subjects countless; his wealth untellable; his power absolute' and having established his own illustrious pedigree, Ahmad recounts his woeful tale of dispossession. There is something troubling about this structure, however. We accept Ahmad's story and the 'real' (as presented by the film in the sequences set outside of Ahmad's tale), as equivalent. However, we do not witness Jaffar's evil outside of Ahmad's account. While admittedly sinister and unpleasant, Jaffar cannot be said to be evil, or unjustified in his actions outside the tale within the film - with one exception that I come back to later. This unquestioning acceptance of Ahmad's account, our unhesitating belief in Jaffar's evil, points to the power of normative discourse to control us, to dictate our likes and dislikes (Gilman 1995: 74).

Practically the whole of the film's first half is narrated by Ahmad who was actually witness to little of what he recounts (and to almost none of Jaffar's evildoings). If, in our analysis of the film, we retain this crucial detail, we can begin 
to see the fault lines on the body of a narrative that masquerades as hegemonic in more ways than one. There is the hegemony implied by the suturing effect of continuity editing; and there is the illusory hegemony of a film that is in part told by an unidentified narrator (the camera or director) and in part told by a character within the film, with his own interests and agenda. In the spirit of Dyer's White (1997), the white British male narrator of large swathes of the film poses as equally 'neutral' and unproblematic as the unidentified camera/director narrator. I pause here to unpick this illusory hegemony, the white male agency that masquerades as the norm, in order to show the complexity of normative discourse.

The two Jaffars - the man and the man as portrayed by Ahmad - are seemingly identical, but there are fundamental differences. Jaffar as represented by Ahmad is a cold, manipulative man who follows a devious plan to dispossess the rightful ruler of Bagdad, usurp his throne, woo his love and conquer the world. First, Jaffar turns the people of Bagdad against their King by implementing excessively harsh laws that punish even the smallest transgression, whether in action or speech. (By comparison, the Sultan of Basra who has his subjects executed on a whim, is presented as a wellmeaning old fool, rather than a bloodthirsty tyrant.) He then tricks the young King into mingling with his people, hoping that they would recognise the latter and take vengeance for the atrocities committed by Jaffar in his name. When the King passes undetected (something that Jaffar could not do, as I discuss later), Jaffar orders that he be arrested and casts him into the dungeons, ordering his execution for the morning. After Ahmad's escape, Jaffar follows him to Basra, where he ingratiates himself to the Sultan by presenting overly lavish gifts before he demands the Sultan's daughter's hand in marriage. The narrative structure (we first see Ahmad meet and fall in love with the Princess, before Jaffar's arrival), suggests that once more, Jaffar is seeking to 
take that which is not his, but Ahmad's. While Jaffar is in audience with the Sultan, Ahmad interrupts and prepares to expose the usurper. Jaffar casts a spell on him, blinding him, and turning Abu into a dog until Jaffar finally holds the Princess in his arms. Here Ahmad's tale ends, and we join the narrative unmediated by any character in the film.

Unmediated Jaffar, however, is a very different man compared to the one presented by Ahmad. It would be an exaggeration to suggest that he is a man who inspires immediate and unreserved confidence, but neither is he an evil, bloodthirsty tyrant. We are introduced to Jaffar briefly in the first scene of the film, where we are invited to observe the colourful, bustling metropolis of Basra. We see Jaffar order his guards to escort a blind beggar and his dog to the palace, where the lowly guests are cared for, fed and watered and generally well treated. We have no time to develop an understanding of the man, however, as Ahmad takes the stage and takes over as narrator. The next time we see Jaffar outside Ahmad's tale is much later in the film. When on board the ship that carries them from Basra, Jaffar enters the berth of the Princess. First, he attempts to overcome her revulsion by forcing her to his will, but he stops. 'No...,' he says. 'I have powers that could force you to my will. But I want more than they can give.' This is not a bloodthirsty rapist, then. Neither is he particularly cruel. But he is immediately and finally rejected by the Princess. Little wonder then that he summons the powers of nature to blow off course the boat in which his rival for the Princess's heart, Ahmad, and Abu follow his ship.

There is one incident, as I suggested earlier, where Jaffar as represented by Ahmad and the 'real' Jaffar overlap, although, with some magnanimity, we could understand Jaffar's motives, especially when considered within the context of patriarchal normative discourse. Having failed to win the Princess's heart, Jaffar tries 
to understand her reasons for steadfastly refusing his courtship: 'You behave like a slave girl,' he tells her, implying that he senses that she submits to him, rather than accepts him. 'You could command me...,' he sighs into her ears, simultaneously suggesting a romantic bent, and belying a lack of insight into power relations between the sexes in a patriarchal system. (This is a crucial flaw as I go on to explore later on: Jaffar cannot possibly fully dismantle a system, or absorb that system, if he cannot fully understand it.) She asks him to take her back to Basra. Ensconced within the Sultan's palace, the Princess takes refuge in the garden, once a bucolic haven of bliss, now a 'place of desolation,' according to the Sultan. She begs him not to allow Jaffar to take her back to Bagdad. Jaffar's response, to murder the Sultan in cold blood, is the one instance where the former's evil arguably overlaps with Ahmad's representation of him. But only if we accept that the Princess's rejection of Jaffar, within the patriarchal system in which both operate, is fair. After all, this is a man who has done nothing or very little wrong up to this point when viewed from within that system. In other words, I am not here arguing for a total absolution of Jaffar's sins but am simply suggesting that by the standards of the mores of the world in which he lives, Jaffar is unfairly judged by his fellow characters. He has charmingly and politely sought the hand in marriage of a Princess, surely a prerogative of the regent of a kingdom. She, at this point, along with everyone else bar Ahmad himself, is unaware that Jaffar had usurped Ahmad's crown. Yet, she in turn treated him with hatred and revulsion. Even before he had a chance to present himself to her, she escaped, exclaiming 'I will never marry him! I would rather die!' Thus patriarchal normative discourse uses the female figure to position the exile within the hierarchy it represents. 
The distinction between Jaffar and Jaffar as represented by Ahmad serves a double purpose. First, it allows us to expose the hidden mechanisms that control our reading of the film, shedding light on our assumption of equivalence between Ahmad's tale and the tale as told by the narrator of the film itself. This, in itself, indicates a problematic illusion of hegemony: an unquestioning acceptance of the white/British/local male voice, and the kneejerk rejection of the exile. Second, it shows that there is a key difference between Jaffar, and the idea of Jaffar formed in the minds of those around him (Jaffar as represented by Ahmad), the implications of which point beyond the mechanisms that govern the power relations of the sexes within a patriarchal order. In other words, Jaffar is outside the human loop (Halberstam, 1998: 15), not just the masculine one. Third, and this follows from these two points, it helps us expose the complex layerings of exclusion and a hierarchy constructed by patriarchal normative discourse, which uses the feminine in order to represent the apartness of the exile, inscribing in the exilic body a conceived difference in the absence of perceivable difference.

This makes it all the more important to examine mainstream cinema's representation of the exile: an understanding of the hidden mechanisms that govern representations of the exilic body could further shed new light on the ways in which patriarchal discourse uses the feminine figure. Armed with this knowledge, and the suspicion that the Jaffar unmediated by film itself is even less 'beyond' or evil, a new reading of the film becomes necessary in order to explore the complex and hitherto unexamined way in which mainstream cinema represents the exilic body.

As I show in what follows, in all Jaffar does, his one motivating factor is to combat universal prejudice, automatic exclusion and rejection in the only way he feels 
will bring results: to remake society in the image of an idealised home, one where he is accepted, loved and respected.

\section{A Tale of Two Thieves}

The film's title in itself gives us a hint as to the true protagonist(s). There are two thieves: one who hails from Bagdad (Abu, thief of/from Bagdad), and one who steals Bagdad (Jaffar, thief of the throne of Bagdad). While the comparison of the two may initially seem forced, it is more than justified. Of all the major characters in the film, only two speak with an accent that is not the King's English ${ }^{4}$. Again, these are Jaffar, who speaks with a crisp precise Germanic accent, and Abu, whose high-pitched voice is coupled with a puzzlingly Germanic diction. Moreover, these two characters are in some way aligned with the animal kingdom. Abu is turned into a dog by Jaffar perhaps an indication of Jaffar's assessment of his own standing in the eyes of those around him. While Jaffar is dehumanised through comparisons with the machinic horse which he gifts to the Sultan, an animal held together by the sheer power of his will. The two exilic bodies, then, represent two different strategies of survival in a hostile host nation. One, Abu, steals small things. He seeks to navigate the margins, to subvert the small rules of life in the host nation in order to find a space he can call his own. The other thief, Jaffar, steals big things. He seeks to liberate himself from the oppression of normative discourse by attempting to recreate his homeland by usurping and transforming the host nation. This transformation, he hopes, will result in the recreation of the conditions under which his can be a secure and stable identity.

Where it seems quite safe to read Abu as an exilic body, it is not quite sufficient to simply state that Veidt is an exilic actor and therefore Jaffar an exilic body. It is necessary to explain how Jaffar is constructed as an exile by the mise-en- 
scène. I have already discussed the film's opening scene, describing Jaffar's arrival in Basra harbour on board his ship. I now return to the scene and examine the use of colour, which, I contend, serves to isolate Jaffar as 'other'.

The immediate impression made by The Thief of Bagdad is one of an explosion of colour: the brilliant deep indigo of the sea, the rich crimson of the sails, even the warm brown and tan of the timber, exhilarate the eye to this day. The ship glides into harbour and we see a city, a cacophony of colours: yellows, reds, greens everywhere. This visual assault, augmented by the blaring soundtrack of a song about men returning from the sea, is giddying.

Alone in this cavalcade is Jaffar, clothed in sombre black; his head is covered by a red turban, his face by a red scarf. These are the only splashes of colour on an otherwise monochromatic frame. One reading of this sobering interruption of black within an overabundance of colour - a reading drawing on Patch's (2010: 74) interpretation of Batchelor's Chromophobia (2000) - would be to suggest an apartness from the 'foreign [...], the primitive, the infantile, the vulgar, the queer or the pathological' of colour (Batchelor 2000: 22-23). However, in a film where the concerns of an insular nation threatened by an external aggressor are made manifest through the reimagining of the nation as a colourful exotic kingdom assaulted by the forces of evil, this reading must be reversed. It is then the monochromatic that comes to stand for 'other', as opposed to the colourful 'norm'. The red of the turban and scarf, then, rather than suggesting a destabilising aspect, an undercurrent of the foreign and/or primitive usually indicated by colour (ibid.: 22-23), suggest a claim to inclusion in the norm. The scarf, however, is drawn over Jaffar's mouth. When he speaks he has to lower the scarf. He cannot speak through the red, the colour as symbol of belonging, precisely because he does not belong. And indeed, the moment 
he opens his mouth and speaks, and we hear the harsh voiceless sibilants and plosives of Veidt's German accent, Jaffar is finally and irreversibly unmasked (quite literally) as the 'other' masquerading as 'one of us'. In contrast with Jaffar, whose inability to integrate is perhaps mirrored by his failure to incorporate colour into his monochromatic frame, Ahmad, once reinstated as rightful king of Bagdad, appears before his subjects in luminous white clothes mottled with splashes of colour. His rationality (as indicated by the white of his attire) is tempered by signs of belonging: the spots of bright colour that dot his royal robes.

Jaffar is reaffirmed as a man apart by the narrative: the story of two men vying for power is told in flashback by one of the two rivals. Jaffar is denied the right to tell his own story, and the neutral account (at least one that is less biased than the unreliable narrative of one with a vested interest in the story but which is still a voice belonging to white patriarchal normative discourse) is delayed until halfway through the film, once an illusion of equivalence has been established between Ahmad's tale and the tale told by the camera-narrator. In other words, just as Jaffar cannot speak through the scarf that is a prop in his masquerade of belonging, so his exilic (accented) voice cannot be heard over that of the white male repository of agency, at least until his evil is fully and finally established in the viewer's mind.

\section{Knowledge in Exile}

From early on Jaffar is introduced as a thinking man; an early hint being the close-up as he removes his scarf and gives a few quietly-spoken orders. Jaffar exudes a cerebral intensity with his rigidly held, controlled body and darting, piercing eyes that suggest a powerful insight and a keen mind. It is immediately clear: this is a scheming man, a clever and dangerous man to boot. This early impression is reinforced by the 
conversation he has on the ramparts of Bagdad castle with the young king. A man is executed in the square below and Ahmad, disgusted by such violence, turns on Jaffar and with unconcealed dislike in his voice asks what the man had done. Jaffar tells him that the man was guilty of thinking, a crime 'quite unpardonable' in a subject. Jaffar, then, is a man who appreciates fully the significance of thought and its relationship to power. He continues: 'Men are evil. Hatred behind their eyes, lies on their lips, betrayal in their hearts.' This is a strange rant coming from a man in a position of great power. He then tries to pass on his knowledge to the king: 'There are but three things that men respect: the lash that descends; the yoke that breaks; and the sword that slays. By the power and terror of these you may conquer the Earth!' These words afford us an insight into the soul of the man (or at least into the soul of the man as represented for us by the white British man, embodied here by Ahmad). He is a man betrayed, misled and loathed. He craves respect, but gets none. He feels his only resort is violence and terror. $\mathrm{He}$ is, also, acutely aware of the importance of knowledge in the delicate task of maintaining a balanced and viable identity in the face of threats to bodily and mental integrity. He understands that he is not accepted, and knows that only violence and the threat of violence can maintain his position in society. The king, Ahmad, however hated he may be as a tyrant in whose name horrible atrocities are daily perpetuated, is accepted by the people as in keeping with the norm - indeed, when Ahmad mingles with his subjects early in the film, he is taken by one and all for one of the people.

When the Sultan of Basra boasts to Jaffar of his cutting-edge mechanical timekeeping device, Jaffar warns him: 'If people once begin to know the time, they will no longer call you the king of time. They will want to know how time is spent.' Again, Jaffar shows that he has a keen understanding of the relationship between knowledge 
and power. Yet, he never succeeds in presenting his power as being 'natural' (Hayward 2000: 89) in the way that Ahmad can. Because he himself does not naturally belong - being an exilic other body - his power cannot be, or at least seem, natural.

Jaffar's failure is his inability properly to master the knowledge specific to the host nation, the knowledge that is necessary for acceptance in the host country. As I discussed above, he shows a keen understanding of the mechanisms of power and is acutely aware of the relationship between knowledge and power. The trouble is that the knowledge Jaffar commands is knowledge that he amassed elsewhere. As a result, his knowledge does not overlap with that of the host nation and is not adequate in his adoptive country. For instance, he firmly maintains that 'men are evil'. A critical knowledge or understanding based on his general knowledge of the world. But Ahmad's reaction makes it clear: Jaffar is fundamentally wrong, and he goes on to say: 'I learned that night not that men are evil, but that he was evil'. Ahmad here displays his capacity to expand his knowledge, while Jaffar seems incapable of learning: he operates with an inflexible mass of knowledge. Jaffar's conclusions are therefore false and undermine his efforts to achieve control of, or power over the host nation. This inability to exert power over members of the host nation is most tellingly illustrated by the scenes where Jaffar uses his powerful mind to control those around him.

Jaffar cannot use performative discourse, in other words he cannot cause members of the host nation to become what he speaks, precisely because his knowledge is not applicable in the host nation. Operating with a knowledge amassed elsewhere, his attempts at discursive performativity (Butler 1993: 12) cannot succeed. Just as he cannot speak through the colourful mask because the other cannot speak 
like 'us', so he cannot cause things to happen by speaking them. When the Sultan takes the flying horse Jaffar has gifted him for a ride above the city, Jaffar thinks, rather than utters, the command that animates the horse. When he blinds Ahmad, he does so silently. The spell is represented as a slowly descending shadow that draws a veil of blindness over Ahmad's eyes. When he seeks to bend the Princess to his will, he does so, again, silently. It is only when he turns Abu into a dog, and when he summons the forces of nature that he speaks the command. The exile can wield iterative performativity, the power of speech, to control the exile or nature, but he has no such power over those from the host nation. He can control the exile, because he has knowledge of the exilic experience. He can control nature, because the other is represented as primitive and therefore close to nature, by normative discourse (Gilman 1985: 29-35). He cannot, however, control members of the host nation because he cannot speak in the voice of the host nation.

Jaffar's astonishing willpower then must not be read as ability above the norm. He has no superpowers. Quite the contrary: he has no power, and therefore must rely on subversive forms of control; Jaffar must exert his control over those around him without recourse to a normative discourse (which is one of the manifestations of knowledge specific to the host nation) that he cannot master. He cannot command others verbally because he cannot conquer the knowledge of the host nation. This inability to command in speech is indicated by the accent that always and immediately identifies the exile as other, as incomplete, as incompetent. It is also this inability that always preys on the mind of the exile, but whose concept they cannot quite grasp. When the Princess once more refuses him, he whispers: 'you could command me'. Jaffar fails to understand that such a submissive attitude towards the 
feminine is in conflict with a patriarchal system that is based upon the denial of feminine corporeality (Butler 1993: 39).

In complete contrast to this ineffectual use of language, the scene where Ahmad first encounters the Princess gives us a good example of the 'norm' when it comes to interaction between the sexes in the context of the film. Ahmad climbs into the forbidden garden and peering down from amongst the foliage of a tree he spies the Princess. She, in turn, spots him but takes him for a genie and he does not correct her mistake. Crucially, their interaction is mediated by the reflective surface of the pond in the garden. She talks to his reflection, and he talks to his own reflection, which, with his complicity, appears as a genie, a spectre. In other words, this is a mise-enscène of a patriarchy that, in Butler's analysis of Irigaray's argument, 'claims to be self-constituting' (1993: 39). As if her argument had been inspired by this scene, Butler writes: 'disavowed, the remnant of the feminine survives as the inscriptional space of that phallogocentrism, the specular surface which receives the marks of a masculine signifying act only to give back a (false) reflection and guarantee of phallogocentric self-sufficiency, without making any contribution of its own' (sic) (ibid). The Princess is disavowed, indeed, sequestered within the confines of a bucolic garden that is completely removed from the space of interaction, the 'social space' (Lefebvre 1991: 34) of the nation. Further, this abundant garden signifies her closeness to nature, and, by extension, her disavowal by a social space dominated by men. She survives as a meaningless, powerless figure, an immaterial surface to be inscribed with meaning through a masculine signifying act. And indeed, it is this projection of the male onto the feminine figure (as played out in a conversation where the male seducer is in effect seducing his own reflection that speaks in the voice of the feminine) that sparks the Princess into a semblance of activity. From this 
encounter on, her activity consists of running away from Jaffar, and then falling into a sort of coma from which only Ahmad's return can rouse her. It is worth noting here that while Jaffar, in his own words, 'has eyes only for [her]', Ahmad had 365 wives as King of Bagdad. Still, or perhaps precisely because of this, Ahmad is the one that can endow her with meaning, while Jaffar can only induce a defiant stupor. In other words, Jaffar, the exilic other male, cannot inscribe this feminine figure with a masculine signifying act. Quite the opposite: he only succeeds in causing the Princess to retreat into a form of suspended animation to prove fully and finally Jaffar's inability to exercise the power that he craves.

Jaffar, willing to submit his will to that of the Princess, cannot understand her revulsion. Of course, this revulsion is not her own, but that of the patriarchal discourse painting the nightmare vision of an exile hoping to find acceptance through the conquest of the feminine. Nor can he understand that he cannot win her love. $\mathrm{He}$ says, 'I have powers that can force you to my will, but I want more than they can give'. He knows that he could force her, but he also understands that to use his powers to force her to him would be, paradoxically, an admission of his own powerlessness, his inability to inspire her love. But he fails to understand (for he lacks the knowledge necessary to reach this realisation) that she will never bend to his will, precisely because he is exilic, and other.

Jaffar's intentions in his pursuit of the Princess are clear from the start. $\mathrm{He}$ arrives in Basra bearing magnificent gifts for the Sultan. He first ingratiates himself to the father then demands the hand in marriage of the daughter. Taken aback, the Sultan asks why. This raises two issues: the fact that the Sultan is shocked by Jaffar's plan to propose to his daughter points to the host nation's instinctive rejection of the exile, especially when it comes to such direct modes of integration; and that also for the 
Sultan it is inconceivable that an exile could be entertaining notions of fathering a child in the host nation. But Jaffar's plan is even more sinister: he hopes to 'set up a dynasty', something that, in Jaffar's own words, is 'quite unpardonable' in an exile. It is when she hears this that the Princess jumps to her feet and prepares to flee from such a threat to her, and by extension - again within the context of a nationalist patriarchal discourse - to the nation's bodily integrity and hegemony.

Jaffar further miscalculates his chances of successfully remaking Bagdad in the image of an idealised homeland. While he succeeds in turning the people against their cruel king, he cannot take his place and claim to be a natural ruler. He can taint the king by association, but he cannot present himself in the king's place as a rightful ruler. He is rebuffed by the Princess, rejected by the Sultan (who agrees to shelter the Princess from him), and is never accepted by the people, who all accept Ahmad when he appears among them as an ordinary man. In other words they reject the real Jaffar, and while they hate the idea of Ahmad (cruel, merciless tyrant), they embrace the real man (wise, warm and truly regal). Apart from his mistake in thinking that with the triple terror of the lash, the yoke and the sword he can conquer Bagdad, let alone the Earth, Jaffar fails to realise that his power cannot seem to be natural (Hayward 2000: 89). His guards are all dressed in identical uniforms. All of them appear as a faceless double of Jaffar himself. They stand tall in dark, monochromatic clothes, their heads covered by a turban, their faces by scarves. Rather than remaking the homeland, these Jaffar-lookalikes serve as a constant reminder of the spreading disease of the other on the body of the nation. Here patriarchal discourses and the discourse of disease meet in a nationalist nightmare of miscegenation, invasion and corruption. The national body reacts quickly: roused by the return of Ahmad, the usurper is summarily ejected 
from the throne, the palace, the city and life itself. Reason returns to its throne as Ahmad takes his rightful place.

\section{Concluding Remarks}

As we have seen, The Thief of Bagdad contributes to a normative discourse that constructs the exilic other as somehow lacking, inferior and intolerable within a nation that defines itself as one, homogenous and whole. A wide variety of strategies are deployed in order to position the exile beyond what is considered human. (Re)iterations of difference, in speech, action and representation are coupled with a complex narrative that seeks to equate the dominant normative voice of the white British male (even if slightly blacked up) with that of the camera-narrator. This blurring of the boundary between the two serves to drive home the irredeemable evil of the subversive, invading exile in a mise-en-scène of threats to the homogeneity and sovereignty of a nation.

It may seem churlish to hold to account for its problematic representation of the foreign 'other' a film whose aim and purpose was as much to entertain as to emphasise the need for national unity in the face of the evil of Nazism spreading through the Continent at the time. But what I hope to have shown is the problematic way in which the body of exilic actors circulate in mainstream cinema. That a film, which can only be applauded for its aim to boost morale in a frightened nation staring into the jaws of utter devastation, should still be found to be engaging in deeply problematic mechanisms of exclusion that have nothing to do with the good fight against Nazi evil, suggests that we must be wary of any cultural product that purports to depict 'the norm', even if its aims, ideologies and world-view seem completely to mesh with our own. 


\section{References}

Aldgate, A. and Richards, J. (1999) Best of British: Cinema and Society from 1930 to the Present new ed., London: IB Tauris.

Armes, R. (1978) A Critical History of British Cinema, London: Secker \& Warburg.

Ashby, J. and Higson, A. (eds.) (2000) British Cinema, Past and Present, London:

Routledge.

Barr, C. (1986) All Our Yesterdays, 90 Years of British Cinema, London: BFI

Publishing.

Batchelor, D. (2000) Chromophobia, Reaktion Books: London.

Bergfelder, T. and Cargnelli, C. (eds.) (2008) Destination London: German-speaking Émigrés and British Cinema, 1925-1950, Oxford: Berghahn Books. -Gemünden, G. (2008) ‘Allegories of Displacement: Conrad Veidt’s British

Films' in T. Bergfelder, T. and C. Cargnelli, (eds.). pp 142-154.

Bernstein, M. and Studlar, G. (eds.) (1997) Visions of the East: Orientalism in Film London: IB Tauris Publishers.

Christie, I. (1985) Arrows of Desire, the Films of Michael Powell and Emeric Pressburger, London: Waterstone. 
Drazin, C. (1998) The Finest Years: British Cinema of the 1940s, London: André Deutsch.

Drazin, C. (2010) 'Korda, Technicolor and the Zeitgeist' Journal of British Cinema and Television 7:1, pp. 5-20.

Dyer, R. (1993) The Matter of Images: Essays of Representation New York:

Routledge.

Dyer, R. (1997) White, London: Routledge.

Eisele, J.C. (2002) 'The Wild East: Deconstructing the Language of Genre in the Hollywood Eastern', Cinema Journal, 41:4, pp 68-94.

Elsaesser, T. (2000) Weimar Cinema and After: Germany's Historical Imaginary, London: Routledge.

Elsaesser, T. (2005) European Cinema, Face to Face with Hollywood, Amsterdam: Amsterdam University Press.

Foucault, M. (2002) The Archaeology of Knowledge, translated by Smith, AMS, London: Routledge Classics.

Garncarz, J. (2006) 'The Ultimate Irony: Jews Playing Nazis in Hollywood' in A. Phillips and G. Vincendeau, (eds.) Journeys of Desire: European actors in Hollywood, a critical companion, London: British Film Institute, pp 103-113.

Gemünden, G. (2003) 'From "Mr. M” to "Mr. Murder": Peter Lorre and the Actor in Exile' in M. McCarthy (ed.) Light Motives: German Popular Film in Perspective, Detroit: Wayne State University Press.

Gilman, S.L. (1985) Difference and Pathology: Stereotypes of Sexuality, Race and Madness Ithaca, NY: Cornell University Press.

Gilman, S.L. (1995) Health and Illness, Images of Difference, London: Reaktion Books. 
Glancy, H.M. (1999) When Hollywood Loved Britain: the 'Hollywood' British Film 1939-1945, Manchester: Manchester University Press.

Hayward, S. (2000) 'Framing National Cinemas' in M. Hjort and S. MacKenzie (eds.), Cinema and Nation, London: Routledge, pp. 88-101.

Higgins, S. (2007) Harnessing the Technicolor Rainbow: Color Design in the 1930s, Austin: University of Texas Press.

Jaikumar, P. (2006) Cinema at the End of Empire, a Politics of Transition in Britain and India, Durham and London: Duke University Press.

Landy, M. (1991) British Genres, Cinema and Society, 1930-1960, Princeton:

Princeton University Press.

Lefebvre, H. (1991) The Production of Space, translated by Nicholson-Smith, D, Oxford: Blackwell.

Murphy, R. (2001) The British Cinema Book $2^{\text {nd }}$ ed., London: BFI Publishing.

Naficy, H. (2001) An Accented Cinema: exilic and diasporic filmmaking, Princeton:

Princeton University Press.

Patch, A. (2010) 'Chromatic Borders, Cosmetic Bodies: Colour in the Films of Nicolas Roeg', Journal of British Cinema and Television 7:1, pp. 69-81.

Philips, A. and Vincendeau, G. eds. (2006) Journeys of Desire: European actors in Hollywood, a critical companion, London: British Film Institute.

Sargeant, A. (2005) British Cinema, A Critical History, London: BFI Publishing. Street, S. (2002) Transatlantic Crossings: British Feature Films in the United States, London: Continuum.

\section{Notes}

${ }^{1}$ William Cameron Menzies was a well-respected production designer who was considered one of the best technicians when it came to colour photography and the production requirements this technology presented (Higgins, 2007: 172-174) 
2 Drazin (2010: 18) does remark on the evil of Veidt's Jaffar and goes on to say that Veidt would later create the role that has come to epitomise Nazi evil on screen, but his purview being a primarily historical one, he does not take this further.

${ }^{3}$ In fact, only the non-Jewish Veidt can be said to have played Nazi villains with any regularity. Usually, but not always, exilic stars played villainous, duplicitous foreign characters, who were often bodily marked. They also played sympathetic characters with some frequency: Veidt, Henreid, Lorre, Lugosi, Lukas have all played warm, friendly figures, who are nonetheless clearly set aside as different and other. Note Henreid's scar in Casablanca (Michael Curtiz, 1942), Lugosi's blacked-up skin in The Return of Chandu (Ray Taylor, 1934), his extravagant Lenin beard in Ninotchka (Ernst Lubitsch, 1939), or Lorre's Japanese makeup in the Mr Moto films (1937-1939).

${ }^{4}$ The only other character that speaks with an accent other than the King's English, is the Djinni (Rex Ingram), who speaks American English. 